\title{
Apparent digestibility of conventional and alternative feedstuffs by hybrid tambacu juveniles
}

\author{
ÁLVARO J.A. BICUDO ${ }^{1}$, THIAGO A.T. ARAUJO ${ }^{2}$, LUÍS G.T. BRAGA ${ }^{3}$, \\ WILLIAM C.T. TONINI ${ }^{4}$ and HAMILTON HISANO ${ }^{5}$ \\ ${ }^{1}$ Universidade Federal do Paraná, Departamento de Zootecnia, Rua Pioneiro, 2153, 85950-000 Palotina, PR, Brazil \\ ${ }^{2}$ Universidade Federal Rural de Pernambuco, Unidade Acadêmica de Garanhuns, \\ Avenida Bom Pastor, s/n, 55292-270 Garanhuns, PE, Brazil \\ ${ }^{3}$ Universidade Estadual de Santa Cruz, Departamento de Ciências Agrárias e Ambientais, \\ Rodovia Jorge Amado, Km 16, 45662-900 Ilhéus, BA, Brazil \\ ${ }^{4}$ Universidade do Estado da Bahia, Departamento de Ciências Humanas e Tecnologias, \\ Rua João Guimarães, s/n, 47400-000 Xique-Xique, BA, Brazil \\ ${ }^{5}$ Embrapa Meio Ambiente, Rodovia SP 340, Km 127,5, s/n, 13820-000 Jaguariúna, SP, Brazil \\ Manuscript received on July 21, 2015; accepted for publication on September 5, 2016
}

\begin{abstract}
The apparent digestibility coefficients (ADC's) of dry matter (DM), crude protein (CP), and gross energy (GE) of conventional feedstuffs (cottonseed meal-CSM, soybean meal-SBM, wheat bran-WHB, corn$\mathrm{COR}$ ) and regional alternative feedstuffs (common bean residue meal-CBR, mesquite meal-MES, pasta byproduct meal-PBM) were determined for hybrid juvenile tambacu Colossoma macropomum $\times$ Piaractus mesopotamicus. The apparent DM and GE digestibility of feedstuffs decreased $(\mathrm{p}<0.05)$ as fiber content of the ingredients increased. No differences $(\mathrm{p}>0.05)$ were found among ADC's of PBM and COR. The lowest CP ADC among energy sources was observed in MES; the lowest CP ADC among plant protein sources was observed in CBR. Information about the ADC's of conventional and alternative feedstuffs for tambacu is essential to formulate low-cost diets and can contribute to regional development.
\end{abstract}

Key words: Characin, fish nutrition, hybrid fish, nutritional value.

\section{INTRODUCTION}

The price and availability of the main feedstuffs used in fish diets affect the profitability of aquaculture. Thus, nutritionists are searching for alternative feedstuffs because these are essential to the expansion of sustainable aquaculture production. A good alternative to replace traditional feedstuffs in fish diets is the use of locally available

Correspondence to: Álvaro José de Almeida Bicudo

E-mail: alvaro.bicudo@ufpr.br new ingredients, especially in regions, such as northeastern Brazil, where the local production of ingredients does not satisfy domestic demand. This could reduce the competition that exists between livestock and aquaculture for conventional ingredients (mainly soybean meal and corn) and reduce feed cost.

Legumes are a traditional source of plant proteins for animal feed; currently, soybean meal is a major plant protein source in omnivorous 
fish diets (Pastore et al. 2012). However, beans and mesquite (Prosopis spp.) are also exploited in many countries in Latin America, Asia and Africa as human and/or animal food (Jones and Mejia 1999, Sawal et al. 2004). Among major food legumes, the common bean (Phaseolus vulgaris L.) is the third most important worldwide, superseded only by soybean and peanuts (Arachis hypogea L.) (Singh 1999). Brazil was the third world dry beans producer in 2014 (FAOSTAT 2016) and the first in the Phaseolus vulgaris (Jones and Mejia 1999). Though there are no current official data on the production of mesquite pods or seeds (Prosopis juliflora), this tree is found globally in rural areas with estimated availability of pods worldwide thought to be 2-4 million metric tons (Sawal et al. 2004). Additionally, one should not neglect the potential for animal consumption of residues in the human food industry. Pasta and bakery byproduct are appointed as dietary corn replacer to different species, as pig (Prandini et al. 2016), dairy cattle (Schroeder 2012) and fish (Lawal et al. 2014, Silva et al. 2014). Brazil ranks third in the global production of pasta, producing more than 1.2 million tons in 2013 (IPO 2014). According Lopes et al. (2009), pasta by-product can represent to around $7 \%$ of the total products generated.

The determination of digestibility is the first step to evaluate the potential of an ingredient for use in aquafeeds. However, species-specific information regarding the digestibility of several feedstuffs is necessary, due to differences in digestive physiology of each species (Tram et al. 2011)

According to the Brazilian Institute of Geography and Statistics, Brazilian aquaculture produced 483,241 tons in 2015. Of this amount, $7.7 \%$ (37,443 ton) were hybrids of tambaqui (Colossoma macropomum) and Piractus species ( $P$. mesopotamicus and P. brachypomus) (IBGE 2016). Despite the economic importance of hybrid fish from indigenous species in Brazil, their nutritional requirements have been neglected. No previous study has surveyed the apparent digestibility of feedstuffs for Brazilian fish hybrids, such as tambacu (C. macropomum $\times$ P. mesopotamicus).

Thus, this study was conducted to determine the apparent digestibility coefficients (ADC's) for dry matter, crude protein and energy of alternative and conventional feedstuffs for hybrid juvenile tambacu.

\section{MATERIALS AND METHODS}

The alternative feedstuffs were selected based on the volume of production and regional (Northeast) availability and consisted of: common bean (Phaseolus vulgaris) residue meal from grains rejected by industry (e.g. broken, with insect larvae) after post-harvest operations, mesquite (Prosopis juliflora) meal manufactured from whole pods collected from trees of wild Caatinga vegetation, pasta by-product composed from broken parts commercially unviable to the human consumer market. Common bean residue and pasta byproduct were provided by small local manufacturers (Garanhuns-PE). The conventional feedstuffs evaluated were: corn, soybean meal, wheat bran, and cottonseed meal; these were purchased from a local supplier (Rancho Alegre ${ }^{\circledR}$, Garanhuns, PE) and showed a commercial standard. The chemical composition of the evaluated ingredients is shown in Table I.

The practical reference diet (Table II) was formulated $\left(30 \% \mathrm{CP} ; 3,400 \mathrm{kcal} \mathrm{DE} \mathrm{kg}{ }^{-1}\right)$ considering the pacu nutrient requirement (Bicudo et al. 2010) due to the absence of information about tambacu requirements. Test diets were formulated combining $70 \%$ of basal diet and $30 \%$ of each test ingredients, added of $0.1 \%$ chromic oxide $\left(\mathrm{Cr}_{2} \mathrm{O}_{3}\right)$ as inert marker. Before the diet was manufactured, all ingredients were finely ground $(0.8-\mathrm{mm}$ particle size) in a hammer mill, weighed, mixed, moistened with $20 \%$ water $(\% \mathrm{v}: \mathrm{w})$, and pelleted in a mincer. 
TABLE I

Chemical composition (dry matter basis) of evaluated ingredients.

\begin{tabular}{lccccccc}
\hline & $\begin{array}{c}\text { Mesquite } \\
\text { meal }\end{array}$ & $\begin{array}{c}\text { Pasta by- } \\
\text { product }\end{array}$ & Wheat bran & Corn & $\begin{array}{c}\text { Cottonseed } \\
\text { meal }\end{array}$ & $\begin{array}{c}\text { Common } \\
\text { bean } \\
\text { residue }\end{array}$ & $\begin{array}{c}\text { Soybean } \\
\text { meal }\end{array}$ \\
\hline Dry matter (\%) & 95.6 & 89.8 & 92.8 & 91.3 & 95.6 & 95.5 & 91.0 \\
Crude protein (\%) & 9.7 & 14.3 & 17.8 & 10.0 & 27.2 & 24.3 & 50.3 \\
Gross energy (kcal/kg) & 4,009 & 2,879 & 4,221 & 3,828 & 4,840 & 4,139 & 4,234 \\
Ether extract (\%) & 2.5 & 2.6 & 7.2 & 10.5 & 11.5 & 3.2 & 4.2 \\
Nitrogen free-extract (\%) & 67.7 & 81.5 & 60.5 & 73.1 & 24.5 & 53.2 & 32.6 \\
Crude fiber (\%) & 16.2 & 0.3 & 9.7 & 4.1 & 32.6 & 14.8 & 6.3 \\
Ash (\%) & 3.9 & 1.3 & 4.8 & 2.3 & 4.2 & 4.5 & 6.6 \\
\hline
\end{tabular}

${ }^{1}$ Calculated by ( 100 - crude protein - ether extract - crude ash - crude fiber).

TABLE II

Ingredients and chemical composition of reference diet.

\begin{tabular}{|c|c|}
\hline Ingredients & $(\%)$ \\
\hline Wheat bran & 37.00 \\
\hline Soybean meal & 21.50 \\
\hline Fish meal & 17.50 \\
\hline Corn starch & 14.07 \\
\hline Corn & 5.00 \\
\hline Soybean oil & 2.31 \\
\hline Vitamin-mineral premix ${ }^{1}$ & 2.50 \\
\hline Chromic oxide & 0.10 \\
\hline $\mathrm{BHT}^{2}$ & 0.02 \\
\hline \multicolumn{2}{|l|}{ Chemical composition (dry matter basis) } \\
\hline Ether extract (\%) & 6.00 \\
\hline Crude fiber $(\%)$ & 6.3 \\
\hline Available phosphorus (\%) & 0.81 \\
\hline Ash $(\%)$ & 8.48 \\
\hline Dry matter $(\%)$ & 95.0 \\
\hline Digestible energy (kcal/kg) & 3,428 \\
\hline Crude protein $(\%)$ & 29.9 \\
\hline \multicolumn{2}{|c|}{$\begin{array}{l}{ }^{1} \text { Contains (quantities } \mathrm{kg}^{-1} \text { premix): vitamins } \mathrm{A}=1,000,000 \mathrm{UI} ; \mathrm{D} 3=312,500 \mathrm{UI} ; \mathrm{E}= \\
18,750 \mathrm{UI} \text { K } 3=1,250 \mathrm{mg} ; \mathrm{B}_{1}=2,500 \mathrm{mg} ; \mathrm{B}_{2}=2,500 \mathrm{mg} ; \mathrm{B}_{6}=1,875 \mathrm{mg} ; \mathrm{B}_{12}=4 \mathrm{mg} \text {; } \\
\text { ascorbic acid }=31,250 \mathrm{mg} \text {; niancin }=12,500 \mathrm{mg} \text {; calcium pantothenate }=6,250 \mathrm{mg} \text {; biotin } \\
=125 \mathrm{mg} \text {; folic acid }=750 \mathrm{mg} \text {; choline }=50,000 \mathrm{mg} \text {; inositol, } 12,500 \mathrm{mg} \text {; minerals: iron } \\
\text { sulfate }=6,250 \mathrm{mg} \text {; copper sulfate }=625 \mathrm{mg} \text {; zinc sulfate }=6,250 \mathrm{mg} \text {; manganese sulfate } \\
=1,875 \mathrm{mg} \text {; sodium selenite }=13 \mathrm{mg} \text {; calcium iodate }=63 \mathrm{mg} \text {; cobalto sulfate }=13 \mathrm{mg} \text {. } \\
{ }^{2} \text { BHT, butylated hydroxytoluene. }\end{array}$} \\
\hline
\end{tabular}

Diets were then dried in a forced ventilation oven $\left(50^{\circ} \mathrm{C} ; 24 \mathrm{~h}\right)$ and dried pellets were stored at $4^{\circ} \mathrm{C}$ until use.

Juvenile tambacu $(17.6 \pm 2.1 \mathrm{~g})$ were stocked in cylindrical plastic cages (60L; 11 fish per cage), then placed in 150-L circular polyethylene tanks (one cage per tank) kept indoors in a recirculating system with constant aeration. The water quality parameters were measured daily: temperature $\left(27.3 \pm 0.3^{\circ} \mathrm{C}\right)$, dissolved oxygen $(8.1 \pm 0.3 \mathrm{mg} / \mathrm{L})$ 
and $\mathrm{pH}(6.4 \pm 0.2)$. All water parameters remained within acceptable values for tambacu, considering the parental species requirements (Araújo-Lima and Gomes 2005, Urbinati and Gonçalves 2005).

Fish were fed their respective diets for a 3-d acclimation period followed by fecal collection period. Fish were hand-fed to apparent satiety in four daily meals (8:00, 11:00, 14:00 and 17:00h). Feed wastes were carefully monitored and prevented using visual cues. One hour after the last daily meal, the fish were transferred in cages into 200L cylindrical-conical digestibility tanks equipped with aeration systems, temperature controls, and refrigerated plastic bottles for feces collection. Feces were collected after $12 \mathrm{~h}$ overnight $(6 \mathrm{pm}$ to $6 \mathrm{am})$ by sedimentation, oven-dried $\left(55^{\circ} \mathrm{C} ; 24 \mathrm{~h}\right)$, grinded and stored under refrigeration $\left(-15^{\circ} \mathrm{C}\right)$ for posterior analysis.

Chemical composition of the diet, feedstuffs and feces was determined according to standard (AOAC 2000) recommendations. Apparent digestibility coefficients for test diets $\left(\mathrm{ADCN}_{\mathrm{D}}\right)$ were calculated according to equation described by (Cho et al. 1982):

$$
A D C N_{D}=100-\left[100\left(\frac{\% \mathrm{Cr}_{2} \mathrm{O}_{3 d}}{\% \mathrm{Cr}_{2} \mathrm{O}_{3 f}}\right) \times\left(\frac{\% N_{f}}{\% N_{d}}\right)\right]
$$

where $\mathrm{ADCN}_{\mathrm{D}}=\mathrm{ADC}$ of a nutrient in the test diets, $\mathrm{Cr}_{2} \mathrm{O}_{3 \mathrm{~d}}=$ chromic oxide in the diet, $\mathrm{Cr}_{2} \mathrm{O}_{3 \mathrm{f}}=$ chromic oxide in the feces, $\mathrm{N}_{\mathrm{f}}=$ nutrients in feces and $\mathrm{N}_{\mathrm{d}}=$ nutrients in the test diets.

The apparent digestibility coefficients of nutrients from each ingredient $\left(\mathrm{ADCN}_{\mathrm{I}}\right)$ were calculated using the following equation (Forster 1999):

$$
A D C N_{I}=\left[\frac{(a+b) \times A D C N_{T}-a \times A D C N_{R}}{b}\right]
$$

where: $a=$ nutrient contribution of reference diet to nutrient content of test diet, $b=$ nutrient contribution of test ingredient to nutrient content of test diet, $(a+b)=$ level of nutrient in combined diet (\%), $\mathrm{ADCN}_{\mathrm{T}}=$ apparent digestibility coefficient of a nutrient in the test diet, and $\mathrm{ADCN}_{\mathrm{R}}=$ apparent digestibility coefficient of a nutrient in the reference diet

The trial was set up in a totally randomized experimental design, with seven treatments and three replicates. Results were submitted to statistical analysis of variance (ANOVA). Means showing significant differences $(p<0.05)$ between treatments were compared by Tukey's test.

\section{RESULTS}

There was a significant $(\mathrm{p}<0.05)$ difference in apparent digestibility (ADC) of dry matter (DM), crude protein (CP) and gross energy (GE) of ingredients by tambacu juveniles (Table III).

The ADC of DM was highest ( $>80 \%)$ in corn, pasta by-product, and soybean meal, although there was no significant difference $(\mathrm{p}>0.05)$ among these feedstuffs. The mesquite meal was the ingredient that registered the lowest value (27.0\%) of DM digestibility and was significantly different $(p<0.05)$ of all ingredients evaluated.

The high protein digestibility values $(>85 \%)$ was observed for five feedstuffs (pasta by-product, wheat bran, corn, cottonseed meal and soybean meal) evaluated. Mesquite meal registered CP digestibility that was significantly lower (27.0\%) than that of common bean residue $(66.3 \%)$.

There was a significant difference $(\mathrm{p}<0.05)$ in ADC of GE (40.2-93.3\%) among the ingredients tested. The higher energy digestibility was obtained in corn, but was similar ( $p>0.05)$ to pasta byproduct. 
TABLE III

Apparent nutrients and energy digestibility coefficients (\%) of different feed ingredients for tambacu juveniles.

\begin{tabular}{|c|c|c|c|c|c|}
\hline \multicolumn{6}{|c|}{ Apparent digestibility coefficients (\%) } \\
\hline & Dry matter & Crude protein & Gross energy & $\begin{array}{c}\text { Digestible } \\
\text { energy }(\mathrm{kcal} / \mathrm{kg})^{1}\end{array}$ & $\begin{array}{c}\text { Digestible } \\
\text { protein }(\%)^{1}\end{array}$ \\
\hline Mesquite meal & $27.0^{\mathrm{a}}$ & $26.7^{\mathrm{a}}$ & $40.2^{\mathrm{a}}$ & 1,612 & 2.6 \\
\hline Pasta by-product & $89.7^{\mathrm{d}}$ & $95.7^{\mathrm{c}}$ & $84.6^{\mathrm{de}}$ & 2,436 & 13.7 \\
\hline Wheat bran & $66.7^{\mathrm{c}}$ & $97.3^{\mathrm{c}}$ & $55.9^{\mathrm{bc}}$ & 2,360 & 17.3 \\
\hline Corn & $90.0^{\mathrm{d}}$ & $94.0^{\mathrm{c}}$ & $93.3^{\mathrm{e}}$ & 3,572 & 9.4 \\
\hline Cottonseed meal & $51.7^{b}$ & $85.7^{\mathrm{bc}}$ & $56.5^{\mathrm{c}}$ & 2,735 & 14.1 \\
\hline Common bean residue & $55.3^{\mathrm{b}}$ & $66.3^{\mathrm{b}}$ & $46.6^{\mathrm{ab}}$ & 1,929 & 13.4 \\
\hline Soybean meal & $84.3^{\mathrm{d}}$ & $90.3^{\mathrm{c}}$ & $78.6^{\mathrm{d}}$ & 3,328 & 45.4 \\
\hline Coefficient of variation (\%) & 10.2 & 9.3 & 5.3 & - & - \\
\hline
\end{tabular}

Values are means of three replicates, and values within the same column with different superscript letters are significantly different $(\mathrm{p} \leq 0.05) .{ }^{1}$ Dry matter basis.

\section{DISCUSSION}

There are similarities between the CPADC observed for soybean meal in this study and those described for other omnivorous species, such as tambaqui (Vidal Júnior et al. 2004), pacu (Abimorad et al. 2008), jundia (Oliveira Filho and Fracalossi 2006), and tilapia (Guimarães et al. 2008, Zhou and Yue 2012). In contrast, Fernandes et al. (2004) registered lower CP digestibility (75.9\%) for soybean meal made from pirapitinga P. brachypomus. Soybean meal showed superior nutritional value for $\mathrm{CP}$ as compared with the other legume meals evaluated (common bean and mesquite) and cottonseed meal. These differences can be explained in part by the presence of anti-nutritional factors and fiber content in feed.

In the present study, the use of raw common bean residue resulted in $\mathrm{ADC}$ of DM, GE and CP lower than that registered for Nile tilapia and black tiger shrimp Penaeus monodon, respectively, feed with soaked + roasted lima bean P. lunatus (Fagbenro 1998) and autoclaved only or autoclaved germinates black gram P. mungo (Kumaraguru Vasagam and Rajkumar 2011). In contrast, the inclusion of $40 \%$ raw black gram does not decrease CP ADC in cyprinid rohu Labeo rohita (Ramachandran and Ray 2007).
The presence of anti-nutritional factors (e.g. trypsin inhibitors, alkaloids, tannins, hemagglutinins) in legumes seeds has been known to negatively affect their use such as alternative protein source (Francis et al. 2001). Galán et al. (2008) registered concentrations of trypsin inhibitor in P. juliflora meal that were 20 times higher (9.32 units of trypsin inhibited/mg dry matter) than those in meal from three other species of Prosopis fruit ( 0.29 to 0.49 units of trypsin inhibited/mg dry matter). Comparatively, trypsin inhibitor activity in Brazilian varieties of common beans ranged from 23.1 to 27.6 units of trypsin inhibited $/ \mathrm{mg}$ (Jourdan et al. 2007). Nevertheless, in the present study, nutritional value of protein from common bean meal was significantly higher than mesquite meal. A possible explanation for this might be that $P$. juliflora seeds are rich in mesquite gum (galactomannans) (Chaires-Martínez et al. 2008). Previous research suggested that galactomannans decrease the availability of nutrients and growth of others species (Hossain et al. 2003, Sawal et al. 2004, Bhatt et al. 2011).

Ingredients containing higher levels (14.8$32.6 \%$ ) of crude fiber, such as common bean residue, mesquite meal, and cottonseed meal showed low values of $\mathrm{DM}, \mathrm{CP}$, and GE ADC. 
Likewise, previous studies have reported a negative correlation between fiber content of the diet and ADC of DM, CP and GE of fish (Tram et al. 2011, Guimarães et al. 2012, Zhou and Yue 2012).

Among the ingredients evaluated, corn and pasta by-product showed the highest and similar ( $>>0.05$ ) ADC's for DM, CP, and GE. The GE digestibility coefficient $(93.3 \%)$ of corn was higher than that those reported for some round fish species, such as pacu (75.8\%) by Abimorad et al. (2008), pirapitinga $(57.6 \%)$ by Vásquez-Torres et al. (2013) and tambaqui (75.0\%) by Gutierrez et al. (2009). This result is in agreement with findings reported by Abimorad et al. (2007) that showed that pacu is capable of digesting and absorbing relative large amounts of carbohydrates.

Studies on the utilization of pasta by-product residue in poultry and broiler chicks have indicated that this ingredient is a potentially useful feed ingredient (Nunes et al. 2001a, b). In the present study, corn and pasta by-product showed similar ADC's. Therefore, the pasta by-product showed potential as corn replacer in diets to tambacu juveniles. However, compared to mesquite meal these energetic ingredients were superior, although nitrogen free-extract values were near among ingredients.

Among the plant protein sources tested, soybean meal was digested more effectively than cottonseed meal and common bean residue meal, showing that tambacu juveniles have low capacity to digest ingredients with high fiber and antinutritional factor content. In general, ADC's of conventional feedstuffs were equivalent compared to parental species. These findings are important for the development of low-cost and balanced rations made from regionally available residues and ingredients for tambacu juveniles.

\section{ACKNOWLEDGMENTS}

This research was funded by Conselho Nacional de Desenvolvimento Científico e Tecnológico (CNPq; Project $n^{\circ}$ 475841/2009-3). The authors are indebted to Comissão Executiva do Plano da Lavoura Cacaueira (CEPLAC) for providing the fish and Fundação de Amparo a Ciência e Tecnologia do Estado de Pernambuco (FACEPE) for scholarship to the second author.

\section{REFERENCES}

ABIMORAD EG, CARNEIRO DJ AND URBINATI EC. 2007. Growth and metabolism of pacu (Piaractus mesopotamicus Holmberg 1887) juveniles fed diets containing different protein, lipid and carbohydrate levels. Aquacult Res 38(1): 36-44.

ABIMORAD EG, SQUASSONI GH AND CARNEIRO DJ. 2008. Apparent digestibility of protein, energy, and amino acids in some selected feed ingredients for pacu Piaractus mesopotamicus. Aquacult Nutr 14(4): 374-380.

AOAC - ASSOCIATION OF OFFICIAL ANALYTICAL CHEMISTS. 2000. Official methods of analysis of AOAC International, $17^{\text {th }}$ ed., Association of Official Analytical Chemists, Gaithersburg.

ARAÚJO-LIMA CARM AND GOMES LC. 2005. Tambaqui (Colossoma macropomum) In: Baldisserotto B and Gomes LC (Eds), Espécies nativas para piscicultura no Brasil. Editora UFSM, Santa Maria, RS, Brasil, p. 67-104.

BHATT SS, CHOVATIYA SG AND SHAH AR. 2011. Evaluation of raw and hydrothermically processed Prosopis juliflora seed meal as supplementary feed for the growth of Labeo rohita fingerlings. Aquacult Nutr 17(2): 164-173.

BICUDO AJA, SADO RY AND CYRINO JEP. 2010. Growth performance and body composition of pacu Piaractus mesopotamicus (Holmberg 1887) in response to dietary protein and energy levels. Aquacult Nutr 16(2): 213-222.

CHAIRES-MARTÍNEZ L, SALAZAR-MONTOYA JA AND RAMOS-RAMÍREZ EG. 2008. Physicochemical and functional characterization of the galactomannan obtained from mesquite seeds (Prosopis pallida). Eur Food Res Technol 227(6): 1669-1676.

CHO CY, SLINGER SJ AND BAYLEY HS. 1982. Bioenergetics of salmonid fishes: energy intake, expenditure and productivity. Comp Biochem Physiol 73B(1): 25-41.

FAGBENRO OA. 1998. Apparent digestibility of various legume seed meals in Nile tilapia diets. Aquacult Int 6(1): 83-87. 
FAOSTAT - FOOD AND AGRICULTURE ORGANIZATION OF THE UNITED NATIONS STATISTICS. 2016. Available at http://faostat3.fao.org/browse/Q/QC/E. Accessed in 04/07/2016.

FERNANDES JBK, LOCHMANN R AND BOCANEGRA FA. 2004. Apparent digestible energy and nutrient digestibility coefficients of diet ingredients for pacu Piaractus brachypomus. J World Aquacult Soc 35(2): 237244.

FORSTER I. 1999. A note on the method of calculating digestibility coefficients of nutrients provided by single ingredients to feeds of aquatic animals. Aquacult Nutr 5: 143-145.

FRANCIS G, MAKKAR HP AND BECKER K. 2001. Antinutritional factors present in plant-derived alternate fish feed ingredients and their effects in fish. Aquaculture 199(3-4): 197-227.

GALÁN AG, CORREAAAD, ABREU CMP AND BARCELOS MFP. 2008. Caracterización química de la harina del fruto de Prosopis spp. procedente de Bolivia y Brasil. Arch Latinoam Nutr 58(3): 309-315.

GUIMARÃES IG, PEZZATO LE AND BARROS MM. 2008. Amino acid availability and protein digestibility of several protein sources for Nile tilapia, Oreochromis niloticus. Aquacult Nutr 14(5): 396-404.

GUIMARÃES IG, PEZZATO LE, BARROS MM AND FERNANDES RN. 2012. Apparent nutrient digestibility and mineral availability of protein-rich ingredients in extruded diets for Nile tilapia. Rev Bras Zoot 41(8): 18011808.

GUTIERREZ FW, ZALDÍVAR J AND CONTRERAS G. 2009. Coeficientes de digestibilidad aparente de harina de pescado peruana y maíz amarillo duro para Colossoma macropomum (Actinopterygii, Characidae). Rev Peru Biol 15(2): 111-115.

HOSSAIN MA, FOCKEN U AND BECKER K. 2003. Antinutritive effects of galactomannan-rich endosperm of Sesbania (Sesbania aculeata) seeds on growth and feed utilization in tilapia, Oreochromis niloticus. Aquacult Res 34: 1171-1179.

IBGE - INSTITUTO BRASILEIRO DE GEOGRAFIA E ESTATÍSTICA. 2016. Produção da pecuária municipal 2015. Disponível em: < https://biblioteca.ibge.gov.br/ visualizacao/periodicos/84/ppm_2015_v43_br.pdf $>$ Acessado em 06/07/2016.

IPO - INTERNATIONAL PASTA ORGANISATION. 2014 The world pasta industry status report 2013. Avalaible at: $<$ http://www.internationalpasta.org/resources/World\%20 Pasta\%20Industry\%20Survey/IPOstatreport2014low.pdf> Accessed in 06/07/2016.

JONES AL AND MEJIA D. 1999. Phaseolus bean: postharvest operations. Roma: Food and Agriculture Organizattion of the United Nations, 25p. Avalaible at: http://www.fao.org/3/a-av015e.pdf. Accessed in: 08/07/2016.

JOURDAN GA, NOREÑA CPZ AND BRANDELLI A. 2007. Inactivation of trypsin inhibitor activity from Brazilian varieties of beans (Phaseolus vulgaris L.). Food Sci Technol Int 13(3): 195-198.

KUMARAGURU VASAGAM KP AND RAJKUMAR M. 2011. Beneficial influences of germination and subsequent autoclaving of grain legumes on proximate composition, antinutritional factors and apparent digestibility in black tiger shrimp, Penaeus monodon Fabricius. Aquacult Nutr 17(2): 188-195.

LAWAL MO, ADEROLU AZ, SERIKI BM AND AARODE OO. 2014. Dietary effects of spaghetti waste as maize replacement in the diet of juvenile African catfish, Clarias gariepinus. Pak J Biol Sci 17: 134-137.

LOPES LFD, BUM DV AND DE GREGORI R. 2009. Identificação das perdas do processo produtivo na fabricação de massas alimentícias: um estudo baseado em sistemas de custos. Ciênc Nat 31(2): 35-56.

NUNES RV, ROSTAGNO HS, ALBINO LFT, GOMES PC AND NASCIMENTO AH. 2001a. Valores de aminoácidos digestíveis verdadeiros e equações de predição dos aminoácidos digestíveis do grão e de subprodutos do trigo para aves. Rev Bras Zoot 30(3): 774-784.

NUNES RV, ROSTAGNO HS, ALBINO LFT, GOMES PC AND TOLEDO RS. 2001b. Composição bromatológica, energia metabolizável e equações de predição da energia do grão e de subprodutos do trigo para pintos de corte. Rev Bras Zoot 30(3): 785-793.

OLIVEIRA FILHO PRC AND FRACALOSSI DM. 2006. Coeficientes de digestibilidade aparente de ingredientes para juvenis de jundiá. Rev Bras Zoot 35(4 - supl.): 15811587.

PASTORE SCG, GAIOTTO JR, RIBEIRO FAS AND NUNES AJP. 2012. Formulação de rações e boas práticas de fabricação. In: Fracalossi DM and Cyrino JEP (Eds), Nutriaqua: nutrição e alimentação de espécies de interesse para a aquicultura brasileira. Florianópolis: Sociedade Brasileira de Aquicultura e Biologia Aquática, p. 295-346.

PRANDINI A, SIGOLO S, MOSCHINI M, GIUBERT G AND MORLACCHINI M. 2016. Effect of the inclusion of dry pasta by-products at different levels in the diet of typical Italian finishing heavy pigs: performance, carcass characteristics, and ham quality. Meat Sci 114: 38-45.

RAMACHANDRAN S AND RAY AK. 2007. Nutritional evaluation of fermented black gram (Phaseolus mungo) seed meal in compound diets for rohu, Labeo rohita (Hamilton), fingerlings. J Appl Ichthyol 23(1): 74-79.

SAWAL RK, RATAN R AND YADAV SBS. 2004. Mesquite (Prosopis juliflora) pods as a feed resource for livestock - a review. Asian Austral J Anim Sci 17(5): 719-725. 
SCHROEDER JW. 2012. By-products and regionally available alternative feedstuffs for dairy cattle. Fargo: North Dakota State University, 16 p. Avalaible at: <https://www. ag.ndsu.edu/pubs/ansci/dairy/as1180.pdf $>$. Accessed in: 08/07/2016.

SILVA TRM, ANDRADE MLS, CHUNG S AND BICUDO AJA. 2014. Substituição parcial do milho pelo resíduo de macarrão em dietas para tilápia-do-Nilo. Bol Inst Pesca 40: 669-676.

SINGH SP. 1999. Production and utilization. In: Singh SP (Ed), Common bean improvement in the twenty-first century. Springer Science+Business Media Dordrecht, Chapter 1, p. 1-24. Kluwer Academic Publishers, Dordrecht.

TRAM NDQ, NGOAN LD, HUNG LT AND LINDBERG JE. 2011. A comparative study on the apparent digestibility of selected feedstuffs in hybrid catfish (Clarias macrocephalus $\times$ Clarias gariepinus) and Nile tilapia (Oreochromis niloticus). Aquacult Nutr 17(2): 636-643.
URBINATI EC AND GONÇALVES FD. 2005. Pacu (Piaractus mesopotamicus). In: Baldisserotto B and Gomes LC (Eds), Espécies nativas para piscicultura no Brasil. Editora UFSM, Santa Maria, RS, Brasil, p. 225255.

VÁSQUEZ-TORRES W, YOSSA MI AND GUTIÉRREZESPINOSA MC. 2013. Digestibilidad aparente de ingredientes de origen vegetal y animal en la cachama. Pesqui Agropecu Bras 48(8): 920-927.

VIDAL JÚNIOR MV, DONZELE JL, ANDRADE DR AND SANTOS LC. 2004. Determinação da digestibilidade da matéria seca e da proteína bruta do fubá de milho e do farelo de soja para tambaqui (Colossoma macropomum), utilizando-se técnicas com uso de indicadores internos e externos. Rev Bras Zoot 33(6 - Supl. 3): 2193-2200.

ZHOU QC AND YUE YR. 2012. Apparent digestibility coefficients of selected feed ingredients for juvenile hybrid tilapia, Oreochromis niloticus $\times$ Oreochromis aureus. Aquacult Res 43(6): 806-814. 